\title{
MSMES THAT RACE IN THE FACE OF ECONOMIC FLUCTUATIONS AND DIGITALIZATION
}

\author{
By Yohane Charlie Raharjo/130119020/PI/KP-A
}

In today's digital era, all community activities cannot be separated from the use of technology. Almost all sectors take advantage of technological developments to innovate not in the business sector, namely Small Micro and Medium Enterprises (MSMEs). MSME itself is defined by various classifications based on capital and business assets consisting of micro, small and medium enterprises. The existence of capital and assets does not always determine that MSMEs can develop in the era of digitalization and the Indonesian economy which is currently experiencing the uncertainty of the COVID-19 pandemic. In a journal article (Tayibnapis, Wuryaningsih, \& Gora, 2021) using qualitative research methods in the case study and it was found that MSMEs have not been able to strengthen the Indonesian economy during the COVID-19 pandemic despite having undergone credit, training, and mentoring programs. Economic fluctuations will be based on real conditions in 2021, namely the COVID-19 pandemic. The government has made various efforts to assist MSMEs in advancing to class, such as direct cash assistance (BLT) in providing initial capital, training and assistance through seminars or webinars that are held, which is still not enough for Indonesian MSMEs to compete in the global market. The main problem now lies in how SMEs can accelerate with innovation and adapt in responding to the development of digital technology and the new normal era. The problem faced is the productivity of business innovation, namely limited access to formal financial institutions, production technology, human resource capacity, raw materials, and marketing. In addition, MSMEs that dominate business units in Indonesia are generally managed informally, with a low level of management education, and labor skills that are not yet optimal. So we need an appropriate system plan and following human resources in Indonesia as well as an effective formal system in running MSMEs in all sectors through government policies. Fiscal policy can encourage the government to cooperate in the successful performance of MSMEs throughout Indonesia. Strengthening innovation for those who are important in supporting inclusive growth by reducing the gap between MSMEs and other large businesses. Increased innovation in MSMEs can be optimized by taking advantage of economic and digital developments that are increasingly accelerated during the new normal. The global community during the Covid-19 pandemic has awakened the contact-free economy and encouraged the transformation of consumer behavior by utilizing digital technology to interact and transact economic and financial. During the Covid-19 pandemic, consumers in Indonesia mostly shopped online and made non-cash transactions, which is expected to continue after the pandemic ends. Responding to the shift in consumer behavior, business actors need to take advantage of increasingly digital platforms, with the push to increase market access being the main incentive. The development of digitalization also offers opportunities for business actors to innovate production processes as well as products and services along with a better understanding of consumer needs and the overall business environment. Apart from the role of MSME actors, the government in this case needs to assist in providing the available telecommunications infrastructure. If both parties can work together with local and global markets, it can be reduced over time and the system. According to (Tayibnapis, Wuryaningsih, \& Gora, 2021) MSMEs need to continue to be improved so that they can be integrated into the national production system or global supply system. MSMEs need to be continuously improved so that they can be integrated into the national production system or global supply chain. In addition, MSMEs must be able to work on local profits to produce special products so that they can be more competitive in both the domestic market and the international market. This pattern has long been applied in Japan, China, and South Korea. Based on this quote, it can be said that 
business actors need to consider appropriately by responding to the local market first before entering the global market. Business actors can use their regional advantages such as the interests and culture of the Indonesian state which is thick with its uniqueness. Examples of uniqueness are typical food, traditional clothing, and so on, there are opportunities for cultural uniqueness that SMEs can use in responding to local and global markets. Marketing of these products is certainly not done traditionally anymore but uses digital technology that is very functional in marketing effectively to target consumers and efficient in the use of time. So, business actors and the government should work together to develop MSMEs that are marketoriented and automated by digital technology.

\section{References}

Tayibnapis, A. Z., Wuryaningsih, L. E., \& Gora, R. (2021). Medium, Small and Medium Enterprises and Digital. South Asian Journal of Social Studies and Economics, 10(2), 10-12.

doi:10.9734/SAJSSE/2021/v10i230258 